\title{
Syllabic Effects in Italian Lexical Access
}

\author{
Lara Tagliapietra - R. Fanari - S. Collina $\cdot$ P. Tabossi
}

Published online: 28 April 2009

(C) Springer Science+Business Media, LLC 2009

\begin{abstract}
Two cross-modal priming experiments tested whether lexical access is constrained by syllabic structure in Italian. Results extend the available Italian data on the processing of stressed syllables showing that syllabic information restricts the set of candidates to those structurally consistent with the intended word (Experiment 1). Lexical access, however, takes place as soon as possible and it is not delayed till the incoming input corresponds to the first syllable of the word. And, the initial activated set includes candidates whose syllabic structure does not match the intended word (Experiment 2). The present data challenge the early hypothesis that in Romance languages syllables are the units for lexical access during spoken word recognition. The implications of the results for our understanding of the role of syllabic information in language processing are discussed.
\end{abstract}

Keywords Syllable $\cdot$ Lexical access $\cdot$ Spoken word recognition · Cross-modal priming · Italian

In the psycholinguistic literature, it is commonly agreed that listeners use syllabic information during speech processing (for a review see Cutler et al. 2001). The role of syllables has been under scrutiny for several years, yet there are still unresolved issues with respect to the function of these units during the early phases of processing that eventually leads to word recognition, i.e. lexical access. An early and well-known theoretical proposal in this regard is the "syllabic hypothesis" (Mehler et al. 1990).

\footnotetext{
L. Tagliapietra $(\varangle)$

Max Planck Institute for Psycholinguistics, P.O. Box 310, 6500 AH, Nijmegen, The Netherlands e-mail: tagliapi@psico.units.it

R. Fanari

University of Cagliari, Cagliari, Italy

S. Collina

Suor Orsola Benincasa University, Napoli, Italy

P. Tabossi

University of Trieste, Trieste, Italy
} 
Initially motivated by developmental considerations (Bertoncini and Mehler 1981; Mehler 1981), the syllabic hypothesis holds that syllables are natural units in speech processing. In the case of Romance languages, listeners rely on these units to accomplish three important processes: to segment the continuous speech signal into discrete chunks (words), to identify phonemes and to establish initial contact with the mental lexicon (Seguí et al. 1990). In these languages, there are relatively few syllabic types and syllables have a simple structure and unambiguous boundaries. Therefore, syllables are the ideal sublexical candidates to mediate between the perceptual input and the lexicon.

Over the years, many studies have been conducted to define the role of syllabic information in speech segmentation and phoneme identification (Bradley et al. 1993; Content et al. 2001b; Dumay et al. 2002; Dupoux 1993; Mehler et al. 1981; Morais et al. 1989; Sebastián-Gallés et al. 1992; Seguí et al. 1981, 1990); but the hypothesis that in Romance languages "the first syllable of an item constitutes the access code, i.e., the minimal amount of information that can activate a cohort of word candidates" (Mehler et al. 1990, p. 255) has prompted limited empirical work. Whereas, seminal psycholinguistic data established that in languages like English and Dutch the first few sounds of a word are sufficient to trigger lexical access (Marslen-Wilson 1987; Zwitserlood and Schriefers 1995); no conclusive data are available on this issue and their interpretations still leave questions open. Do speakers of Romance languages behave differently from English and Dutch speakers? Do they delay lexical access until the first syllable is recognized, as posited by the standard syllabic theory (Mehler 1981; Mehler et al. 1981, 1990; Seguí et al. 1990)? The goal of this paper is to elucidate this issue in Italian.

Seguí (1984) conducted in French the first study specifically devoted to the role of the syllable during lexical access. Seguí hypothesized that if words were accessed by their initial syllable, lexical factors would affect detection times in syllable monitoring differently in mono- and polysyllabic carrier items. If a target syllable is not a word (e.g., CRA), its identification in mono- and bi-syllabic carrier items (e.g., cra and cratère, crater) should be equally fast, as no lexical factors are involved in either condition. In contrast, if the target syllable is a word (e.g., CRI), its identification coincides with the identification of the word when the carrier is a monosyllabic item (e.g., cri, cry). In this case lexical information is immediately available and may help syllable identification. Polysyllabic words, however, cannot usually be identified by their initial syllable. Therefore, accessing the initial syllable of a bi-syllabic word (e.g., critère, criterion) provides listeners with no lexical information and syllable identification must be performed on the basis of pre-lexical information, which creates a disadvantage in this condition compared with the monosyllabic carrier. The results corroborated these predictions: Non-word targets were identified equally fast in mono- and bi-syllabic carrier items, whereas word targets yielded faster responses in mono- than in bi-syllabic carrier items. And, the author interpreted the results as evidence that "access to the lexicon on monosyllabic words is obligatory, whereas for polysyllabic items the first syllable serves for purposes of initial access. The first syllable of a word can thus be considered a key to lexical access"(Seguí 1984, p. 165).

Seguí drew similar conclusions from the results of a second experiment, in which French listeners were asked to monitor pre-specified phonemes (e.g., /d/) in sentential contexts (e.g., L'institutrice a été convoquée par le d... pour faire sa connaissance, The tutor has been invited by the ... to be introduced). Target phonemes (e.g., /d/) appeared at the onset of a carrier word with high transitional probability and two carrier words with low transitional probability. Carriers with low transitional probability shared with high-transitional probability words 
(e.g., di\#recteur ${ }^{1}$ director) either the initial syllable (e.g., di\#rigeant, manager) or the initial phoneme (e.g., dé\#legue, delegate). Targets' detections were equally fast in high and low transitional carrier words that shared the first syllable. In contrast, detections in low transitional carriers that shared only the first phoneme with high transitional words were reliably slower than in high transitional carriers. These results corroborate Seguí's basic prediction that the comparison between expected words and the actual initial sounds is performed on the basis of syllabic units.

Dupoux and Mehler (1990) also addressed the role of syllables in lexical access with a logic similar to Seguí (1984) first study. They tested whether a typical lexical factor, such as word frequency, affects French listeners' latencies during phoneme monitoring in both mono- and polysyllabic carriers. Phoneme identifications were faster in high frequency carriers than in low frequency carriers, but only in monosyllabic words. No difference was observed between latencies in low and high frequency polysyllabic words, suggesting that for these carriers lexical access had not been yielded yet.

While compatible with the hypothesis that words are accessed by their initial syllable, this evidence is hardly conclusive. The monitoring studies comparing lexical effects in monoand polysyllabic words successfully show that lexical information becomes available very quickly upon the presentation of monosyllabic words and may intervene in syllable and phoneme detections (Cutler et al. 1987). However, they give no indication as to whether during the early phases of word recognition the first contact with the mental lexicon is actually established by a word's initial syllable, as claimed by the theory. Furthermore, almost all the studies on the role of the syllable as access unit have been conducted using monitoring tasks, and it is well known that data collected with these techniques often reflect decision processes rather than processing phenomena (Cutler et al. 1987; Kolinsky 1998; Pitt and Samuel 1990).

So far, there is only one study that employed an on-line methodology-the cross-modal semantic fragment priming - to test the role of syllables as access units (Tabossi et al. 2000). In Experiment 5 of this study, participants were asked to listen to sentences ending with a CVC fragment (e.g., La prossima parola è sil..., The next word is /sil/ ...) and to make lexical decisions on visual targets (e.g., RUMORE, noise) presented at the offset of the fragments. As predicted by the syllabic hypothesis, responses were faster when the fragments derived from words semantically associated with the targets (e.g., /si\#l/ from si\#lenzio, silence) ${ }^{1}$ with respect to when fragments had a different syllabic structure and derived from unrelated words (e.g., /sil/ from sil\#vestre, silvan). These findings, which are consistent with the predictions of the syllabic hypothesis, were obtained with unstressed fragments. The choice was justified by the intention of testing the syllabic hypothesis under the most favourable conditions. Within a language, unstressed syllables are typically shorter and lower in intensity than stressed syllables. They provide listeners with an input that is acoustically less clear than the input provided by stressed syllables, and it is precisely under these conditions that, according to the proponents of the theory, listeners are more likely to rely on syllabic units (Sebastián-Gallés et al. 1992). Indeed, in a cross-linguistic segment-monitoring study, Sebastián-Gallés et al. (1992) replicated the syllabic effects in Catalan only with non initial-stressed carrier words, and failed to find the effect at all in Spanish. As with Spanish, Italian listeners are sensitive to syllabic structure when monitoring phonemes in the attention paradigm but not in a simple segment-monitoring task, regardless of stress position (Tabossi et al. 2000). It is still an empirical question, however, whether in Italian the role of the syllable during lexical access depends on lexical stress position. (Tabossi et al. 2000).

1 The symbol \# marks a syllabic boundary. 
According to Thornton et al. (1997) approximately one third of the Italian lexicon is constituted by initial-stressed words, and it would be very harmful for the syllabic hypothesis if its claims did not apply to this portion of the lexicon. Hence, testing whether the syllabic effects observed in non initial-stressed words extend to initial-stressed words was the aim of Experiment 1.

\section{Experiment 1}

As in Tabossi et al. (2000), participants listened to word fragments in the context of a carrier sentence. At the offset of the fragments, they were visually presented with a target word on which they performed a lexical decision task. The priming fragments were three phonemes long, and had been excised from a word whose initial syllabic structure was CV\#C, from a word with the same initial phonemes, but whose initial syllabic structure was CVC\# and from a control word. Unlike Tabossi et al. (2000), all the words from which fragments were extracted were stressed on the first syllable.

Visual targets were presented under three experimental conditions (see Table 1). In the related condition the priming fragments derived from words semantically associated with the targets. In the unrelated condition the fragments contained the same phonemes as the fragments in the related condition, but they had a different syllabic structure and derived from words semantically unrelated to the targets. Finally, in the control condition the fragments contained phonemes different from those in the other conditions, and derived from words unrelated to the targets.

Within the currently accepted framework in which spoken word recognition is conceived as a process requiring the initial activation of a set of lexical candidates, the syllabic view holds that the perceptual unit used to form this initial set is the syllable. Words sharing the first syllable with the to-be-recognized word will enter the set, whereas words sharing the same initial phonemes, but with a different syllabic structure will not. For instance, pa\#ne (bread) would be included in the initial set activated by the syllable pa\# in /pa\#n/, but would not enter the set activated by /pan\#/. Similarly, cal\#do (warm) would be activated by the syllable $/ \mathrm{kal} \# /$, but would receive no activation from the initial syllable in /ka\#l/.

In the cross-modal semantic paradigm, the activation of the prime is measured by the relative amount of facilitation that it produces on the responses to the target. According to the syllabic hypothesis, only fragments in the related condition should activate the mental representation of the lexical items semantically associated with the visual targets, facilitating the responses to them. Latencies should, therefore, be reliably faster in this condition than

Table 1 Examples of the materials used in Experiment 1

$\mathrm{CV} \quad \mathrm{CVC}$

\begin{tabular}{lllll}
\hline Related & pa\#n(e) & Bread & cal\#(do) & Warm \\
Unrelated & pan\#(ca) & Bench & ca\#l(ice) & Goblet \\
Control & do\#n(o) & Present & tor\#(ta) & Cake \\
Target & CIBO & FOOD & FREDDO & COLD
\end{tabular}

Note: $\mathrm{CV}$ and CVC refer to the structure of the first syllable of the word from which the related fragment has been obtained. Visual targets are in capital letters. All the fragments were inserted in the preceding sentential context La prossima parola è ... (The next word is ...) 
in the unrelated and the control conditions, where the fragments should not activate lexical representations associated with the targets.

Method

\section{Participants}

Forty-two undergraduates native speakers of Italian volunteered for the experiment. All had normal hearing and normal or corrected-to-normal vision. None had previously participated in an experiment of this sort.

\section{Materials}

Thirty Italian words (nouns and adjectives), stressed on the first syllable, were selected. In half of them the initial syllable had a CV structure, and in half it had a CVC structure. All the syllables had unambiguous boundaries. The words (henceforth: related words) were of medium/high frequency $(\mathrm{M}=110, \mathrm{SD}=107)$ : $138(\mathrm{SD}=138)$ for the $\mathrm{CV}$, and $82(\mathrm{SD}=58)$ for the CVC words on average (out of 500,000 occurrences: Bortolini et al. 1972). They were selected so as to have the highest frequency among the initial-stressed content words beginning with the same three phonemes. ${ }^{2}$

For each related word, two new words (nouns or adjectives), also stressed on the first syllable, were chosen. In one of them the first three phonemes were the same as in the related word, but the syllabic structure was different (unrelated word). In the other (control word), the first syllable had the same structure as in the related word, but different phonemes. The mean frequency of the unrelated words was $25(\mathrm{SD}=57): 17(\mathrm{SD}=25)$ for the CVC words and $35(\mathrm{SD}=77)$ for the $\mathrm{CV}$ words. The mean frequency of the control words was 47 $(\mathrm{SD}=87)$ : $43(\mathrm{SD}=39)$ for the $\mathrm{CV}$ words and $51(\mathrm{SD}=120)$ for the CVC words (Bortolini et al. 1972).

From each related, unrelated and control word a fragment made up of the three initial phonemes was obtained to use as related, unrelated and control prime in the experiment. None of the fragments, except for bar, was an Italian word. The mean number of words compatible with the related and unrelated fragments was assessed by means of an Italian dictionary (Devoto and Oli 1971). The count included initial-stressed words beginning with the same phonemes and syllabic structure as the fragments. ${ }^{3}$ Only stems were considered; inflected, derived, and compound words were not treated as separate items. The mean number of competitors was $4.30(\mathrm{SD}=3.25)$ for the related fragments $(3.20$, $\mathrm{SD}=1.57$ for the $\mathrm{CV}$, and $5.40, \mathrm{SD}=4.10$ for the $\mathrm{CVC}$ fragments), and 4.80 ( $\mathrm{SD}=4.08$ ) for the unrelated fragments $(6.20, \mathrm{SD}=4.77$ for the $\mathrm{CVC}$, and $3.40, \mathrm{SD}=2.75$ for the $\mathrm{CV}$

2 Because of the difficulty in finding materials with the appropriate characteristics, five of the 30 selected words (two $\mathrm{CV}$ and three $\mathrm{CVC}$ ) had one higher frequency competitor. The words and their competitors were: sale-sala (salt-room), sole-solo (sun-only), carta-caro (paper-dear), sangue-santo (blood-saint), and semplice-sembra (simple-it seems).

3 Only words with both the same syllabic structure and the same lexical stress position entered the two competitor sets. The first constraint was suggested by the hypothesis being tested; indeed, if it were not introduced, related and unrelated fragments would generate exactly the same candidate sets. Lexical stress effects in free-stress languages motivate the second constraint (Cooper et al. 2002; van Donselaar et al. 2005; Soto-Faraco et al. 2001). In Italian stress is unpredictable and distinctive (e.g., 'capito-ca'pito, I turn upunderstood, cala'mita-calami'ta, magnet-disaster, 'principi-prin' cipi, princes-principles; Bertinetto 1981 and personal communication) and recent data indicate that Italian listeners rely on lexical stress position to reduce the number of competitors during spoken word recognition (Tagliapietra and Tabossi 2005). 
fragments). Each of the fragments was inserted in the carrier sentence La prossima parola $\grave{e} . .$. (The next word is...), yielding thirty related, thirty unrelated, and thirty control sentences.

Thirty new words were also selected. They were semantically associated with the words from which the related fragments were obtained (Parisi and Pizzamiglio 1967) and used as visual targets, each paired with one triplet of related, unrelated, and control sentences. Experimental materials are listed in Appendix A.

In addition, 70 filler fragments, similar in syllabic structure and length to the experimental fragments, were made up and inserted in the carrier sentence. They derived from words selected according to the same criteria as the experimental items: 20 were paired with word and 50 with legal pseudoword targets. Finally, nine training trials were constructed conforming to the experimental specifications.

SoundEdit software running on a Macintosh Computer was used to edit the speech material. A female Italian speaker recorded the carrier sentence and all the words. Both experimental and filler words were truncated at the offset of the third phoneme. Experimental items were recorded on one channel of a cassette, whereas an inaudible 1000-Hz pulse was placed at the end of the fragments on the other channel of the cassette.

The mean duration of the CV\#C related, CVC\# unrelated and CV\#C control fragments was $426 \mathrm{~ms}(\mathrm{SD}=46), 428 \mathrm{~ms}(\mathrm{SD}=45)$, and $420 \mathrm{~ms}(\mathrm{SD}=56)$ respectively; they did not reliably differ from one another: $F(2,42)=.106, M S E=2447$, n.s. The mean duration of the CVC\# related, CV\#C unrelated and CVC\# control fragments were $395 \mathrm{~ms}(\mathrm{SD}=48)$, $392 \mathrm{~ms}(\mathrm{SD}=43)$, and $399 \mathrm{~ms}(\mathrm{SD}=54)$ respectively. Again, they did not reliably differ from one another: $F(2,42)=.086, M S E=2336$, n.s.

The mean duration of the steady states of the vowels was $156 \mathrm{~ms}(\mathrm{SD}=38)$ in the related $\mathrm{CV} \# \mathrm{C}$ fragments and $110 \mathrm{~ms}(\mathrm{SD}=27)$ in the unrelated CVC\# fragments; the difference was reliable: $F(1,28)=21.06, M S E=738, p<.01$. Also reliable was the difference between the duration of the steady states of the vowels in the related CVC\# fragments $(\mathrm{M}=106, \mathrm{SD}=26)$ and in the unrelated $\mathrm{CV} \# \mathrm{C}$ fragments $(\mathrm{M}=131, \mathrm{SD}=39): F(1,28)=$ 6.60, MSE718, $p=.016$.

To ensure that participants would perceive the experimental fragments correctly, these were divided into three lists of 30 items each. Each list contained one fragment from each experimental triplet and an equal number of related, unrelated and control fragments. An independent panel of 30 Italian native speakers (ten per list) was randomly assigned to one of the lists. The participants were asked to listen to each fragment and to write down exactly what they heard. Their responses were collected and analyzed. The overall percentage of correct recognitions - in which the listeners reported the three phonemes actually pronounced-was $88.66 \%(91 \%, 86.66 \%$, and $88.33 \%$ for the related, the unrelated, and the control fragments, respectively). The incorrect recognitions $(11.34 \%)$ consisted of misperceptions or deletions of one phoneme $(9.17 \%)$, and anticipations of a fourth phoneme $(2.17 \%)$.

A stimulus set containing all the visual targets was created to be paired with each list of 100 sentences. Three lists were created; each included the 70 filler trials, but different experimental trials. If one list included the related sentence of one triplet, the second list included the unrelated sentence, and the third list the control sentence. Each list was divided into two blocks of 50 trials. Within each block, there was an equal number of word and pseudoword targets and an equal number of trials for each of the experimental conditions. Within lists, trials occurred in a random order. 


\section{Procedure and Design}

The experiment was individually run in a soundproof room. The participant sat in front of the computer display. For each trial, s/he heard a sentence over headphones and, at the offset of the prime, saw a target. The participant was instructed to press a key with his/her dominant hand as soon as possible if the target was a word, and to do nothing otherwise. The pulse placed at the offset of each fragment caused a visual target to be presented on the screen of the computer for $1500 \mathrm{~ms}$. It also started a timer which stopped when the participant pressed a key; if there was no response, it reset automatically after $2 \mathrm{~s}$. There was a $5 \mathrm{~s}$ interval between trials.

After the training trials, each participant was randomly assigned to one of the experimental lists. List and block presentation orders were balanced across participants. The experiment lasted about $20 \mathrm{~min}$. Reaction times (henceforth: RTs) and errors were collected.

There were two independent variables: the structure of the related priming fragment

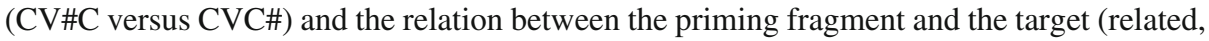
unrelated and control).

\section{Results and Discussion}

Figure 1 shows the mean latencies of correct responses in the experimental conditions. RTs above and below two standard deviations from the mean were excluded from further analyses. The overall percentage of errors (including false alarms, misses, and outliers) was $5.40 \%$.

Latencies were submitted to two ANOVAs. In the participants' analysis $\left(F_{1}\right)$, both variables were within; in the items' analysis $\left(F_{2}\right)$, the structure of the related priming fragment was a between factor and the relation between the priming fragment and the target was a within factor. The relation between priming fragment and target was the only significant factor: $\left.F_{1}(2,82)=8.63, M S E=1375, p<.001 ; F_{2}(2,56)=3.93, M S E=1105, p=.025\right)$.

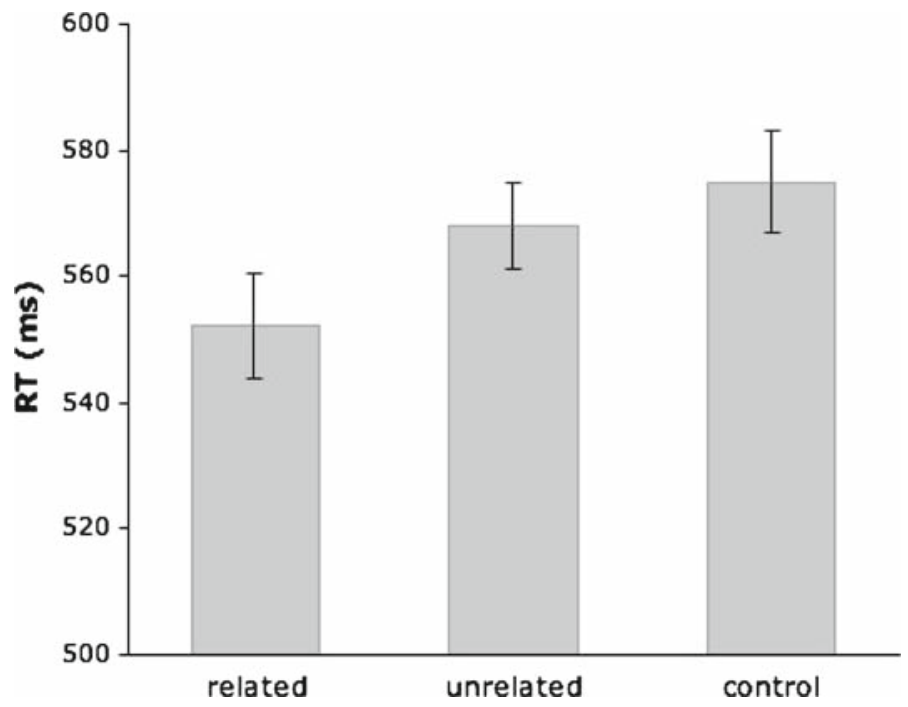

Fig. 1 Mean RTs in milliseconds and standard errors of correct responses as a function of the experimental conditions in Experiment 1 
Planned, non-orthogonal comparisons showed that responses were significantly faster in the related $(552 \mathrm{~ms}, \mathrm{SD}=53)$ than in the unrelated condition $(568 \mathrm{~ms}, \mathrm{SD}=44)$; which, in turn, did not reliably differ from the control $(575 \mathrm{~ms}, \mathrm{SD}=51)$ condition (related versus unrelated: $F_{1}(1,41)=5.42, M S E=1595, p=.025 ; F_{2}(1,28)=3.94, M S E=1063, p=$ .057 ; unrelated versus control: $F_{1}(1,41)=2.65, M S E=1352$, n.s.; $F_{2}(1,28)=.73$, $M S E=896$, n.s.). No other main factor or interaction was significant in any analysis.

Fragments in the related condition successfully activated the mental representation of the lexical candidates semantically associated with the visual targets. There is no evidence that the same representations were activated by the unrelated primes. As reflected in the different mean frequencies of the related and unrelated words, to maximize the possibility of the unrelated fragments activating the mental representations of the related words, these were selected so as to be the most frequent among the items starting with the same phonemes, regardless of structure. Even so, no reliable facilitation effects were found in the unrelated condition.

The findings replicate and extend to stressed fragments the data reported by (Tabossi et al. 2000). They corroborate the predictions that naturally follow from the syllabic hypothesis, providing a strong piece of evidence in its support. However, alternative interpretations are possible. Listeners, for instance, could exploit the acoustic differences between vowels in the related and unrelated fragments without ever detecting syllables.

The explanation of the findings provided by the syllabic hypothesis rests on the assumption that listeners perceive differently fragments such as /pa\#n/ and /pan\#/, and hence activate different sets of lexical candidates. In particular, when listening to a CV\#C fragment, people identify the initial syllable and use it to activate a number of lexical hypotheses beginning with that syllable. These candidates are never accessed by a CVC\# fragment, which sends activation only to lexical candidates beginning with that syllable. In order to clarify this issue, the empirical adequacy of this hypothesis was tested in Experiment 2.

\section{Experiment 2}

Within the theoretical framework of the syllabic hypothesis, one study reported by Dupoux (1993) investigated the possibility that a sub-syllabic unit might give access to the lexicon. French listeners monitored for initial phonemes in monosyllabic CV, CVC, and CCV words and pseudowords. The results showed that phoneme identifications were faster in $\mathrm{CV}$ and CCV words than in pseudowords, whereas no difference was observed with CVC items. Dupoux argued that the lack of a difference between CVC words and pseudowords is what one would expect if listeners perform phoneme identification based on the information provided by the $\mathrm{CV}$ part of a CVC word. As acknowledged by the author, these findings are only suggestive of the role that sub-syllabic information might have on access.

To collect direct evidence as to whether a fragment shorter than a syllable can establish contact with the lexicon, we asked our participants to make lexical decisions on visual targets presented at the offset of the open part of CVC syllables. These CV fragments derived from words whose initial syllable was stressed and had a CVC structure (e.g., /ku/ from cur\#va, bend). In the test condition the fragments shared the phonemes with the first CV syllable of a word (e.g., cu\#ra, treatment) associated with the visual target (e.g., MEDICO, doctor). In the control condition, the fragments derived from words (e.g., /fa/ from fal\#so, false) not related to the visual targets. The two conditions are illustrated in Table 2.

According to the syllabic model, a syllabic unit must be identified before the input can start to send activation to the lexicon. Hence, a sub-syllabic unit, such as the priming fragments 
Table 2 An example of the test and control conditions in Experiment 2

\begin{tabular}{lll}
\hline Test condition & cu(r\#va) & Bend \\
Control condition & fa(l\#so) & False \\
Target & MEDICO & DOCTOR \\
\hline
\end{tabular}

Note: All the fragments were inserted in the preceding sentential context La prossima parola è ... (The next word is ...)

in this experiment, should fail to activate lexical candidates, and lexical decision latencies should show no reliable differences in the test and the control conditions.

In contrast, if the identification of a syllabic unit is not needed to access the lexicon (Marslen-Wilson 1987; Zwitserlood and Schriefers 1995), the open part of a CVC syllable should be sufficient to contact the lexicon, sending activation to the mental representation of the words that match the perceptual input, regardless of structure. Under these assumptions, the fragments in the test condition should activate, among other lexical candidates, the representations of the words semantically associated with the targets, facilitating lexical decisions to them. Responses should therefore be faster in the test than in the control condition.

Method

\section{Participants}

Thirty undergraduates native speakers of Italian volunteered for the experiment. All had normal hearing and normal or corrected-to-normal vision. None had previously participated in an experiment of this sort.

\section{Materials}

Sixteen pairs of polysyllabic Italian words, all stressed on the first syllable, were selected. One word in each pair had a CVC initial syllable. The other word shared the same two initial phonemes with the CVC word, but its first syllable had a CV structure. All the words had clear syllabic boundaries. CV words were selected so as to have the highest frequency among the initial-stressed words beginning with the same two phonemes. ${ }^{4}$ Their mean frequency was accordingly higher than that of CVC words $(224, \mathrm{SD}=258$ and $132, \mathrm{SD}=235$, respectively: Bortolini et al. 1972).

From each CVC word, a fragment formed by the two initial phonemes was obtained to

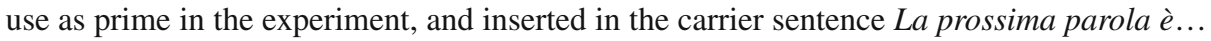
(The next word is ...). Finally, for each CV word, a new word, semantically associated with it, was selected as visual target. Experimental materials are listed in Appendix B.

In addition, 16 filler fragments, similar to the experimental ones, were created and inserted in the carrier sentence. They derived from words selected according to the same criteria as the experimental items and were paired with 16 legal pseudowords to use as visual targets. Finally, 10 training trials were constructed conforming to the experimental specifications.

Experimental materials were recorded and edited as in the previous experiment, except that words were truncated at the offset of the second phoneme.

4 Due to the difficulty in the selection of materials, two of the pairs did not conform to the criteria: nor\#mano\#bile (norm-noble) and sal\#to-sa\#le (jump-salt). In these pairs, the CV word was not the most frequent among the words beginning with the same two phonemes. 
The mean duration of the experimental fragments was $270 \mathrm{~ms}(\mathrm{SD}=44)$. To ensure that participants in the experiment would perceive the experimental fragments correctly, ten Italian speakers, who did not participate in the experiment proper, were asked to listen to each fragment and to write down exactly what they heard. Their responses were collected and analyzed. The overall percentage of correct recognitions was $95.50 \%$. The incorrect recognitions $(4.50 \%)$ consisted of misperceptions of one of the phonemes.

One list of 32 sentences-16 experimental and 16 filler-was created. It was paired with two sets of visual targets. Both sets included all the targets - 16 words and 16 legal pseudowords. Pseudowords occurred in the same positions in the two sets, paired with the same filler sentences. Word targets, however, occurred in different positions such that a word target which was paired with a test prime in one set, was paired with a control prime in the other set and vice versa. Each set contained an equal number of targets in the test and control conditions. Within the list, trials occurred in a random order.

\section{Procedure and Design}

The procedure was the same as in the previous experiment. After the training trials, an equal number of participants was randomly assigned to one set. The experiment lasted about $15 \mathrm{~min}$. RTs and errors were collected. The only independent variable was the relation between priming fragments and targets (test versus control).

\section{Results and Discussion}

Outliers were identified as in the previous experiment. The overall percentage of errors (including false alarms, misses, and outliers) was $4.79 \%$. Figure 2 shows the mean latencies of correct responses in the experimental conditions. Latencies were submitted to participants and items ANOVAs. In both analyses the only factor was within.

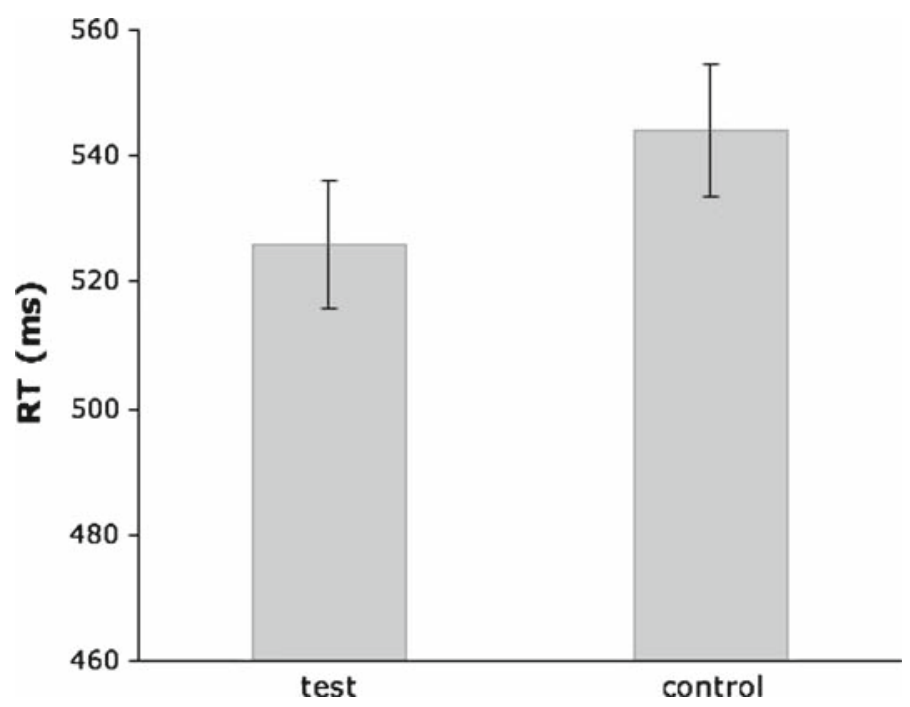

Fig. 2 Mean RTs in milliseconds and standard errors of correct responses as a function of the experimental conditions in Experiment 2 
Participants were reliably faster at deciding that a target was a word in the test $(526 \mathrm{~ms}$, $\mathrm{SD}=55)$ than in the control condition $(544 \mathrm{~ms}, \mathrm{SD}=57): F_{1}(1,29)=5.22, M S E=$ $924, p=.03 ; F_{2}(1,15)=5.30, M S E=452, p=.04$.

Contrary to the predictions of the syllabic hypothesis, the open part of a CVC syllable facilitates lexical items related to words whose initial syllables have a CV structure. These findings rule out the possibility that the differences in the related and unrelated conditions observed in Experiment 1 reflect differences in the way in which listeners access the lexicon as a function of whether or not the initial CV part of a fragment is actually a syllable.

Probably, listeners used these initial parts to activate a set of lexical candidates, irrespective of whether they had a CV\#C or a CVC\# structure. Only later in the process, when information relative to the subsequent consonants became available, they reduced the initial set of candidates according to the new information.

\section{General Discussion}

Two cross-modal experiments explored the empirical adequacy of the syllabic theory of lexical access in Italian. Experiment 1 extends Tabossi et al. (2000) findings and indicates that the structural effect predicted by the syllabic hypothesis is not restricted to unstressed syllables. Participants were faster at making a lexical decision to a visual target after listening to a three phoneme long fragment derived from a word semantically associated with the target than after listening to a fragment containing the same phonemes, but derived from an unrelated word with a different syllabic structure. Responses in this condition did not reliably differ from responses in a control condition. However, the results of Experiment 2 indicate that these structural effects cannot be ascribed to the syllable as a unit for lexical access. The body of a CVC stressed syllable definitely activates a candidate set that includes CV\# initial words.

In contrast with previous evidence (Dupoux and Mehler 1990; Seguí 1984), these findings fail to support the view that in Romance languages lexical access is mediated by syllablelike units, as proposed by the syllabic theory [in its original form]. The difference is most likely to reflect the use of different paradigms. Unlike prior research, conducted with monitoring techniques, this study employed the cross-modal semantic priming paradigm. This paradigm tested on-line the effectiveness of word initial fragments to activate lexical representations by looking at the amount of facilitation they produced on responses to visual targets semantically associated with the words starting with those fragments. As the most complex experimental techniques, this paradigm is open to several potential criticisms (Glucksberg et al. 1986; Koriat 1988; Kieger and Glass 1983; Lorch et al. 1986; Lupker 1984). However, it has now been the object of intense scrutiny, and a substantial amount of work has shown its reliability (Burgess et al. 1989; Peterson and Simpson 1989). In fact, the technique has been extensively used to investigate access to semantically or syntactically ambiguous words (Gow and Gordon 1995; Marslen-Wilson and Zwitserlood 1989; Onifer and Swinney 1981; Tabossi 1988; Tanenhaus et al. 1979), and it has also been successfully employed to study phenomena of multiple activation in the processing of lexically ambiguous strings (Shillcock 1990; Tabossi et al. 2000; Zwitserlood 1989; Zwitserlood and Schriefers 1995). The present research corroborates and extends prior evidence, showing that two phoneme long fragments can activate lexical representations to a level that is sufficient to produce semantic priming.

Taken together, the present findings are not compatible with the classical syllabic hypothesis, but with a revised cascade version of it (Dupoux 1993) that allows for the initial activation of candidates compatible with the open part of a CVC syllable. Later in the process, when the 
full CVC syllable is recognized, the set of lexical candidates is reduced accordingly. Thus, as long as the set of syllabic candidates activated by the initial part of a CVC syllable includes the open syllable itself, the cascade model can accommodate the results of Experiment 2.

Different kinds of information may assist listeners during the discrimination of CV\#C and CVC\# structures. Vowels are longer in open than in closed syllables and also vowelconsonant formant transitions differ depending on whether the latter resides in coda or in onset position (Fowler 1981; Maddieson 1985; Vayra 1996); finally, consonants are differently realized with respect to their position (onset versus coda) in the syllabic structure (Lehiste 1964).

Experiment 2 results suggest that listeners relied neither on the duration of the vowel nor on the vowel-consonant transition. In fact, in Experiment 2 a CV unrelated prime (e.g., $/ \mathrm{ku} /$ from cur\#va, bend), containing a vowel realized in a closed nucleus, facilitated a target (e.g., MEDICO, doctor) related to a word beginning with an open syllable (e.g., cura, treatment). More likely, in Experiment 1 and in Tabossi et al. (2000) Experiment 5, listeners took advantage of acoustic differences in the last consonant of the fragments.

A growing body of evidence, actually, indicates that listeners are sensitive to fine details of consonantal realizations during spoken word recognition. Dutch listeners, for instance, rely on the different duration of a consonant (e.g., /s/) to discriminate between ambiguous portions of speech, like eens pot versus een spot, once jar versus one mockery (Shatzman and McQueen (2006)). Furthermore, Sawusch (1977) reported data suggesting that the perceptual processing discriminates between phonemically identical consonants occurring either at the onset or at the offset of the syllabic structure.

A recent model of spoken word recognition, moreover, can account for this interpretation. Most of the current models, such as TRACE (McClelland and Elman 1986), Shortlist (Norris 1994) and DCM (Gaskell and Marslen-Wilson 1997) do not include structural information and cannot account for the present findings. Nevertheless PARSYN (Luce et al. 2000), a recent connectionist version of NAM (Luce and Pisoni 1998), captures syllabic effects. This model proposes an allophonic intermediate level of processing, instead of either a phonemic level of representation (TRACE and Shortlist) or a direct feature input to the lexical level (DCM). At this level, consonantal allophones that occur either in onset or in offset position of a syllable are represented and allow the recognition of the third consonant $/ \mathrm{n} / \mathrm{of}$ the fragment prime pan as either the allophone of the word pa\#ne (bread) or of the word pan\#ca (bench).

The present findings complement several lines of research that have called into question various claims of the syllabic theory. Its inadequacy with respect to phoneme identification (Dupoux 1993; van Son and Pols 1999) has already been documented and also its role as a unit of segmentation and classification has already been challenged (Banel and Bacri 1994; Content et al. 2001a; Dumay et al. 2002). For example, in a series of word spotting experiments, Dumay et al. (2002) asked French listeners to detect monosyllabic targets (e.g., lac) in nonsense strings in which the target was either aligned or misaligned with a syllable boundary (e.g., zun\#lac versus zu\#glac). The authors argued that the larger processing costs observed for misalignment at target onset (e.g., zun\#lac versus zu\#glac) with respect to target offset (e.g., la\#cluf versus lac\#tuf) suggest that, in French, syllable onsets rather than syllabic units are crucial in the segmentation of continuous speech.

This study establishes that in Italian the process of lexical access is not mediated by syllable-like perceptual units, as these are not critical to establish initial contact with mental word representations. In fact, in Romance as well as other languages no single unit can guarantee lexical access, and modeling the initial phases of access requires the exact specification of the perceptual and lexical factors leading to the activation of the initial set of lexical candidates. 
Acknowledgements The present research was supported by grants MURST ex 40\% and 60\%. We would like to thank Pier Marco Bertinetto, Cristina Burani, Alessandro Laudanna, Giovanna Marotta, Marina Nespor and Roger Wales for their valuable suggestions.

Appendix A Experimental materials (and English translations) employed in Experiment 1

\begin{tabular}{|c|c|c|c|c|c|c|c|}
\hline \multicolumn{8}{|c|}{ CV\#C related primes } \\
\hline Related & Unrelated & Control & Target & Related & Unrelated & Control & Target \\
\hline $\begin{array}{l}\text { Cane } \\
\text { (dog) }\end{array}$ & $\begin{array}{l}\text { Canto } \\
\text { (singing) }\end{array}$ & $\begin{array}{l}\text { Gola } \\
\text { (throat) }\end{array}$ & $\begin{array}{l}\text { GATTO } \\
\text { (СAT) }\end{array}$ & $\begin{array}{l}\text { Barba } \\
\text { (beard) }\end{array}$ & $\begin{array}{l}\text { Bara } \\
\text { (coffin) }\end{array}$ & $\begin{array}{l}\text { Tenda } \\
\text { (tent) }\end{array}$ & $\begin{array}{l}\text { BAFFI } \\
\text { (MOUSTACHE) }\end{array}$ \\
\hline $\begin{array}{l}\text { Fine } \\
\text { (end) }\end{array}$ & $\begin{array}{l}\text { Finto } \\
\text { (false) }\end{array}$ & $\begin{array}{l}\text { Lino } \\
\text { (linen) }\end{array}$ & $\begin{array}{l}\text { INIZIO } \\
\text { (BEGINNING) }\end{array}$ & $\begin{array}{l}\text { Caldo } \\
\text { (warm) }\end{array}$ & $\begin{array}{l}\text { Calice } \\
\text { (goblet) }\end{array}$ & $\begin{array}{l}\text { Torta } \\
\text { (cake) }\end{array}$ & $\begin{array}{l}\text { FREDDO } \\
\text { (COLD) }\end{array}$ \\
\hline $\begin{array}{l}\text { Lana } \\
\text { (wool) }\end{array}$ & $\begin{array}{l}\text { Lancio } \\
\text { (throw) }\end{array}$ & $\begin{array}{l}\text { Giro } \\
\text { (turn) }\end{array}$ & $\begin{array}{l}\text { SETA } \\
\text { (SILK) }\end{array}$ & $\begin{array}{l}\text { Carta } \\
\text { (paper) }\end{array}$ & $\begin{array}{l}\text { Caro } \\
\text { (expensive) }\end{array}$ & $\begin{array}{l}\text { Burla } \\
\text { (trick) }\end{array}$ & $\begin{array}{l}\text { PENNA } \\
\text { (PEN) }\end{array}$ \\
\hline $\begin{array}{l}\text { Magro } \\
\text { (thin) }\end{array}$ & $\begin{array}{l}\text { Magma } \\
\text { (magma) }\end{array}$ & $\begin{array}{l}\text { Gufo } \\
\text { (owl) }\end{array}$ & $\begin{array}{l}\text { GRASSO } \\
\text { (FAT) }\end{array}$ & $\begin{array}{l}\text { Corpo } \\
\text { (body) }\end{array}$ & $\begin{array}{l}\text { Coro } \\
\text { (choir) }\end{array}$ & $\begin{array}{l}\text { Zampa } \\
\text { (paw) }\end{array}$ & $\begin{array}{l}\text { MENTE } \\
\text { (MIND) }\end{array}$ \\
\hline $\begin{array}{l}\text { Male } \\
\text { (evil) }\end{array}$ & $\begin{array}{l}\text { Malto } \\
\text { (malt) }\end{array}$ & $\begin{array}{l}\text { Pila } \\
\text { (battery) }\end{array}$ & $\begin{array}{l}\text { BENE } \\
\text { (GOOD) }\end{array}$ & $\begin{array}{l}\text { Forte } \\
\text { (strong) }\end{array}$ & $\begin{array}{l}\text { Foro } \\
\text { (hole) }\end{array}$ & $\begin{array}{l}\text { Borsa } \\
\text { (bag) }\end{array}$ & $\begin{array}{l}\text { DEBOLE } \\
\text { (WEAK) }\end{array}$ \\
\hline $\begin{array}{l}\text { Mano } \\
\text { (hand) }\end{array}$ & $\begin{array}{l}\text { Mancia } \\
\text { (tip) }\end{array}$ & $\begin{array}{l}\text { Bacio } \\
\text { (kiss) }\end{array}$ & $\begin{array}{l}\text { PIEDE } \\
\text { (FOOT) }\end{array}$ & $\begin{array}{l}\text { Lampada } \\
\text { (lamp) }\end{array}$ & $\begin{array}{l}\text { Lamina } \\
\text { (sheet) }\end{array}$ & $\begin{array}{l}\text { Dondolo } \\
\text { (gift) }\end{array}$ & $\begin{array}{l}\text { LUCE } \\
\text { (LIGHT) }\end{array}$ \\
\hline $\begin{array}{l}\text { Mare } \\
\text { (sea) }\end{array}$ & $\begin{array}{l}\text { Marcia } \\
\text { (march) }\end{array}$ & $\begin{array}{l}\text { Pala } \\
\text { (shovel) }\end{array}$ & $\begin{array}{l}\text { ONDE } \\
\text { (WAVES) }\end{array}$ & $\begin{array}{l}\text { Largo } \\
\text { (large) }\end{array}$ & $\begin{array}{l}\text { Larice } \\
\text { (larch) }\end{array}$ & $\begin{array}{l}\text { Parte } \\
\text { (part) }\end{array}$ & $\begin{array}{l}\text { STRETTO } \\
\text { (NARROW) }\end{array}$ \\
\hline $\begin{array}{l}\text { Pane } \\
\text { (bread) }\end{array}$ & $\begin{array}{l}\text { Panca } \\
\text { (bench) }\end{array}$ & $\begin{array}{l}\text { Dono } \\
\text { (gift) }\end{array}$ & $\begin{array}{l}\text { CIBO } \\
\text { (FOOD) }\end{array}$ & $\begin{array}{l}\text { Lungo } \\
\text { (long) }\end{array}$ & $\begin{array}{l}\text { Luna } \\
\text { (moon) }\end{array}$ & $\begin{array}{l}\text { Dolce } \\
\text { (sweet) }\end{array}$ & $\begin{array}{l}\text { CORTO } \\
\text { (SHORT) }\end{array}$ \\
\hline $\begin{array}{l}\text { Pino } \\
\text { (pine tree) }\end{array}$ & $\begin{array}{l}\text { Pingue } \\
\text { (fat) }\end{array}$ & $\begin{array}{l}\text { Muro } \\
\text { (wall) }\end{array}$ & $\begin{array}{l}\text { ABETE } \\
\text { (FIR TREE) }\end{array}$ & $\begin{array}{l}\text { Morte } \\
\text { (death) }\end{array}$ & $\begin{array}{l}\text { Mora } \\
\text { (blueberry) }\end{array}$ & $\begin{array}{l}\text { Polso } \\
\text { (wrist) }\end{array}$ & $\begin{array}{l}\text { VITA } \\
\text { (LIFE) }\end{array}$ \\
\hline $\begin{array}{l}\text { Ramo } \\
\text { (branch) }\end{array}$ & $\begin{array}{l}\text { Rampa } \\
\text { (slope) }\end{array}$ & $\begin{array}{l}\text { Ladro } \\
\text { (thief) }\end{array}$ & $\begin{array}{l}\text { ALBERO } \\
\text { (TREE) }\end{array}$ & $\begin{array}{l}\text { Pompa } \\
\text { (pump) }\end{array}$ & $\begin{array}{l}\text { Pomo } \\
\text { (apple) }\end{array}$ & $\begin{array}{l}\text { Nervi } \\
\text { (nerves) }\end{array}$ & $\begin{array}{l}\text { BICICLETTA } \\
\text { (BICYCLE) }\end{array}$ \\
\hline $\begin{array}{l}\text { Rana } \\
\text { (frog) }\end{array}$ & $\begin{array}{l}\text { Rango } \\
\text { (range) }\end{array}$ & $\begin{array}{l}\text { Zona } \\
\text { (zone) }\end{array}$ & $\begin{array}{l}\text { STAGNO } \\
\text { (POND) }\end{array}$ & $\begin{array}{l}\text { Ritmo } \\
\text { (rhythm) }\end{array}$ & $\begin{array}{l}\text { Rito } \\
\text { (ritual) }\end{array}$ & $\begin{array}{l}\text { Palmo } \\
\text { (palm) }\end{array}$ & $\begin{array}{l}\text { MUSICA } \\
\text { (MUSIC) }\end{array}$ \\
\hline $\begin{array}{l}\text { Sale } \\
\text { (salt) }\end{array}$ & $\begin{array}{l}\text { Salto } \\
\text { (jump) }\end{array}$ & $\begin{array}{l}\text { Mela } \\
\text { (apple) }\end{array}$ & $\begin{array}{l}\text { PEPE } \\
\text { (PEPPER) }\end{array}$ & $\begin{array}{l}\text { Sangue } \\
\text { (blood) }\end{array}$ & $\begin{array}{l}\text { Sano } \\
\text { (healthy) }\end{array}$ & $\begin{array}{l}\text { Lento } \\
\text { (slow) }\end{array}$ & $\begin{array}{l}\text { ROSSO } \\
\text { (RED) }\end{array}$ \\
\hline $\begin{array}{l}\text { Sole } \\
\text { (sun) }\end{array}$ & $\begin{array}{l}\text { Solco } \\
\text { (furrow) }\end{array}$ & $\begin{array}{l}\text { Dama } \\
\text { (lady) }\end{array}$ & $\begin{array}{l}\text { CALDO } \\
\text { (WARM) }\end{array}$ & $\begin{array}{l}\text { Semplice } \\
\text { (easy) }\end{array}$ & $\begin{array}{l}\text { Semina } \\
\text { (sowing) }\end{array}$ & $\begin{array}{l}\text { Tartaro } \\
\text { (tartar) }\end{array}$ & $\begin{array}{l}\text { DIFFICILE } \\
\text { (DIFFICULT) }\end{array}$ \\
\hline $\begin{array}{l}\text { Vero } \\
\text { (true) }\end{array}$ & $\begin{array}{l}\text { Verde } \\
\text { (green) }\end{array}$ & $\begin{array}{l}\text { Pena } \\
\text { (pain) }\end{array}$ & $\begin{array}{l}\text { FALSO } \\
\text { (FALSE) }\end{array}$ & $\begin{array}{l}\text { Soldi } \\
\text { (cash) }\end{array}$ & $\begin{array}{l}\text { Solito } \\
\text { (usual) }\end{array}$ & $\begin{array}{l}\text { Campo } \\
\text { (field) }\end{array}$ & $\begin{array}{l}\text { DENARO } \\
\text { (MONEY) }\end{array}$ \\
\hline $\begin{array}{l}\text { Vino } \\
\text { (wine) }\end{array}$ & $\begin{array}{l}\text { Vinto } \\
\text { (defeated) }\end{array}$ & $\begin{array}{l}\text { Cura } \\
\text { (treatment) }\end{array}$ & $\begin{array}{l}\text { ACQUA } \\
\text { (WATER) }\end{array}$ & $\begin{array}{l}\text { Torto } \\
\text { (wrong) }\end{array}$ & $\begin{array}{l}\text { Toro } \\
\text { (bull) }\end{array}$ & $\begin{array}{l}\text { Zinco } \\
\text { (zinc) }\end{array}$ & $\begin{array}{l}\text { RAGIONE } \\
\text { (RIGHT) }\end{array}$ \\
\hline
\end{tabular}

Priming fragments are in bold and visual targets in capital letters 
Appendix B Experimental materials (and English translations) employed in Experiment 2

\begin{tabular}{|c|c|c|c|c|c|}
\hline \multirow{2}{*}{$\begin{array}{l}\text { Primes } \\
\text { Benda }\end{array}$} & \multicolumn{2}{|c|}{ Associate and target words } & \multirow{2}{*}{$\begin{array}{l}\text { Primes } \\
\text { (bandage) }\end{array}$} & \multicolumn{2}{|c|}{ Associate and target words } \\
\hline & Bene & MALE & & (good & $\mathrm{BAD})$ \\
\hline Certo & Celebre & FAMOSO & (certain) & (well-known & FAMOUS) \\
\hline Cinque & Cinema & FILM & (five) & (cinema & FILM) \\
\hline Curva & Cura & MEDICO & (bend) & (treatment & DOCTOR) \\
\hline Dolce & Dopo & PRIMA & (sweet) & (after & BEFORE) \\
\hline Falso & Facile & DIFFICILE & (false) & (easy & DIFFICULT) \\
\hline Gilda & Giro & TONDO* & (gild) & (turn & ROUND) \\
\hline Lingua & Lira & MONETA & (tongue) & (lira & COIN) \\
\hline Lungo & Luce & SOLE & (long) & (light & SUN) \\
\hline Marcia & Madre & PADRE & (march) & (mother & FATHER) \\
\hline Nembo & Nero & BIANCO & (cloud) & (black & WHITE) \\
\hline Norma & Nobile & CONTE & (norm) & (Noble & COUNT) \\
\hline Porta & Poco & TANTO & (door) & (little & MUCH) \\
\hline Salto & Sale & PEPE & (jump) & (salt & PEPPER) \\
\hline Sempre & Secolo & MILLENNIO & (always) & (century & MILLENNIUM) \\
\hline Sunto & Subito & ADESSO & (summary) & (immediately & NOW) \\
\hline
\end{tabular}

Priming fragments are in bold and paired visual targets, preceded by their associates, are in capital letters

* In Italian, Giro tondo means Ring-a-ring-o' roses.

\section{References}

Banel, M. H., \& Bacri, N. (1994). On metrical patterns and lexical parsing in French. Speech Communication, $15,115-126$.

Bertinetto, P. M. (1981). Strutture prosodiche dell'italiano. Firenze: Accademia della Crusca.

Bertoncini, J., \& Mehler, J. (1981). Syllables as units in infant speech perception. Infant Behavioral Development, 4, 247-260.

Bortolini, U., Tagliavini, C., \& Zampolli, A. (1972). Lessico di frequenza della lingua italiana contemporarea. Milano: Garzanti.

Bradley, D. C., Sánchez-Casas, R. M., \& García-Albea, J. E. (1993). The status of the syllable in the perception of Spanish and English. Language and Cognitive Processes, 8, 197-233.

Burgess, C., Tanenhaus, M. K., \& Seidenberg, M. S. (1989). Context and lexical access: Implications of nonword interference for lexical ambiguity resolution. Journal of Experimental Psychology: Learning, Memory, and Cognition, 15, 620-632.

Content, A., Kearns, R. K., \& Frauenfelder, U. H. (2001a). Boundaries versus onsets in syllabic segmentation. Journal of Memory and Language, 45, 177-199.

Content, A., Meunier, C., Kearns, R., \& Frauenfelder, U. H. (2001b). Sequence detection in pseudowords in French: Where is the syllable effect? Language and Cognitive Processes, 16, 609-636.

Cooper, N., Cutler, A., \& Wales, R. (2002). Constraints of lexical stress on lexical access in English: Evidence from native and non-native listeners. Language and Speech, 45, 207-228.

Cutler, A., Mehler, J., Norris, D., \& Seguí, J. (1987). Phoneme identification and the lexicon. Cognitive Psychology, 19, 141-177.

Cutler, A., McQueen, J. M., Norris, D., \& Somejuan, A. (2001). The roll of the silly ball. In E. Dupoux (Ed.), Language, brain and cognitive development: Essays in honor of Jacques Mehler (pp. 181-194). Cambridge, MA: MIT Press.

Devoto, G., \& Oli, G. C. (1971). Dizionario della lingua italiana. Firenze: Le Monnier.

Dumay, N., Frauenfelder, U. H., \& Content, A. (2002). The role of the syllable in lexical segmentation in French: word-spotting data. Brain \& Language, 81, 144-161.

Dupoux, E. (1993). The time course of pre-lexical processing: The syllabic hypothesis revisited. In G. Altmann \& R. Shillcock (Eds.), Cognitive models of speech processing ( $\mathrm{pp} \mathrm{81-114).} \mathrm{Hove:} \mathrm{Erlbaum.}$ 
Dupoux, E. \& Mehler, J. (1990). Monitoring the lexicon with normal and compressed speech: Frequency effects and the pre-lexical code. Journal of Memory and Language, 29, 316-335.

Fowler, C. (1981). A relation between coarticulation and compensatory shortening. Phonetica, 38, 35-50.

Gaskell, M. G., \& Marslen-Wilson, W. D. (1997). Integrating form and meaning: A distributed model of speech perception. Language and Cognitive Processes, 12, 613-656.

Glucksberg, S., Kreutz, R. J., \& Rho, S. (1986). Context can constrain lexical access: Implications for a model of language comprehension. Journal of Experimental Psychology: Learning, Memory, and Cognition, 3, 323-333.

Gow, D. W., \& Gordon, P. C. (1995). Lexical and prelexical influences on word segmentation: Evidence from priming. Journal of Experimental Psychology: Human Perception and Performance, 21, 344-359.

Kieger, J. L., \& Glass, A. L. (1983). The facilitation of lexical decision by a prime occurring after the target. Memory and Cognition, 11, 356-365.

Kolinsky, R. (1998). Spoken word recognition: A stage processing approach to language differences. The European Journal of Cognitive Psychology, 10, 1-40.

Koriat, A. (1988). Semantic facilitation in lexical decision as a function of prime-target association. Memory and Cognition, 9, 587-598.

Lehiste, I. (1964). Acoustical characteristics of selected english consonants. Bloomington, IN: Indiana University.

Lorch, R. F., Jr., Balota, D. A., \& Stamm, E. G. (1986). Locus of inhibition effects in the priming of lexical decisions: Pre- or postlexical access? Memory and Cognition, 14, 95-103.

Luce, P. A., Goldinger, S. D., Auer, E. T., \& Vitevitch, M. S. (2000). Phonetic priming, neighborhood activation, and PARSYN. Perception \& Psychophysics, 62, 615-625.

Luce, P. A., \& Pisoni, D. B. (1998). Recognizing spoken words: The neighborhood activation model. Ear and Hearing, 19, 1-36.

Lupker, S. J. (1984). Semantic priming without association: A second look. Journal of Verbal Learning and Verbal Behavior, 23, 709-733.

Maddieson, J. (1985). Phonetic cues to syllabification. In V. Fromkin (Ed.), Linguistic phonetics. Essays in Honor of Peter Ladefoged (pp. 203-221). Orlando: Academic Press.

Marslen-Wilson, W. D. (1987). Functional parallelism in spoken word-recognition. Cognition, 25, 71-102.

Marslen-Wilson, W. D., \& Zwitserlood, P. (1989). Accessing spoken words: The importance of word onsets. Journal of Experimental Psychology: Human Perception and Performance, 115, 576-585.

McClelland, J. L., \& Elman, J. F. (1986). The TRACE model of speech perception. Cognitive Psychology, 18, $1-86$.

Mehler, J. (1981). The role of syllables in speech processing: Infant and adult data. Philosophical Transactions of the Royal Society, London, Series B, 295, 333-352.

Mehler, J., Dommergues, J., Frauenfelder, U., \& Seguí, J. (1981). The syllables role in speech segmentation. Journal of Verbal Learning and Verbal Behavior, 20, 298-305.

Mehler, J., Dupoux, E., \& Seguí, J. (1990). Constraining models of lexical access: The onset of word recognition. In G. T. M. Altmann (Ed.), Cognitive models of speech processing: Psycholinguistic and computational perspectives (pp. 236-262). Cambridge, Mass: MIT Press.

Morais, J., Content, A., Cary, L., Mehler, J., \& Seguí, J. (1989). Syllabic segmentation and literacy. Language and Cognitive Processes, 4, 57-67.

Norris, D. (1994). Shortlist: A connectionist model of continuous speech recognition. Cognition, 52, 189-234.

Onifer, W., \& Swinney, D. A. (1981). Accessing lexical ambiguity during sentence comprehension: Effects of frequency of meaning and contextual bias. Memory and Cognition, 9, 225-236.

Parisi, D., \& Pizzamiglio, L. (1967). Dati quantitativi sulle associazioni verbali di studenti italiani. Roma: Bulzoni.

Peterson, R. R., \& Simpson, G. B. (1989). Effect of backward priming on word recognition in single-word and sentence contexts. Journal of Experimental Psychology: Learning, Memory, and Cognition, 15, 1020-1032.

Pitt, M. A., \& Samuel, A. G. (1990). Attentional allocation during speech perception: How fine is the focus? Journal of Memory and Language, 29, 611-632.

Sawusch, J. R. (1977). Processing of place information in stop consonants. Perception \& Psychophysics, 22, 417-426.

Sebastián-Gallés, N., Dupoux, E., Segui, J., \& Mehler, J. (1992). Contrasting syllabic effects in Catalan and Spanish. Journal of Memory and Language, 31, 18-32.

Seguí, J. (1984). The syllable: A basic unit in speech perception? In H. Bouma \& D. G. Bouwhuis (Eds.), Attention and performance X, control of language processes (pp. 165-181). Hillsdale, NJ. Erlabum.

Seguí, J., Dupoux, E., \& Mehler, J. (1990). The role of the syllable in speech segmentation, phoneme identification, and lexical access. In G. T. M. Altmann (Ed.), Cognitive models of speech processing: Psycholinguistic and computational perspectives (pp. 263-280). Cambridge, Mass: MIT Press. 
Seguí, J., Frauenfelder, U. H., \& Mehler, J. (1981). Phoneme monitoring, syllable monitoring, and lexical access. British Journal of Psychology, 72, 471-477.

Shatzman, K. B. \& McQueen, J. M. (2006). Segment duration as a cue to word boundaries in spoken-word recognition. Perception \& Psychophysics, 68, 1-16.

Shillcock, R. (1990). Lexical hypotheses in continuous speech. In G. T. M. Altmann (Ed.), Cognitive models of speech processing: Psycholinguistic and computational perspectives (pp. 24-49). Cambridge: MA: MIT Press.

Soto-Faraco, S., Sebastián-Gallés, N., \& Cutler, A. (2001). Segmental and suprasegmental mismatch in lexical access. Journal of Memory and Language, 45, 412-432.

Tabossi, P. (1988). Accessing lexical ambiguity in different types of sentential contexts. Journal of Memory and Language, 27, 324-340.

Tabossi, P., Collina, S., Mazzetti, M., \& Zoppello, M. (2000). Syllables in the processing of spoken Italian. Journal of Experimental Psychology: Human Perception and Performance, 26, 1-18.

Tagliapietra, L. \& Tabossi, P. (2005). Lexical stress effects in Italian spoken word recognition. In Proceedings of the 27th annual conference of the cognitive science society (pp. 2140-2144).

Tanenhaus, M. K., Leiman, J. M., \& Seidenberg, M. S. (1979). Evidence for multiple stages in the processing of ambiguous words in syntactic contexts. Journal of Verbal Learning and Verbal Behavior, 18, 427-440.

Thornton, A. M., Iacobini, C., \& Burani, C. (1997). BDVDB. Una base di dati sul Vocabolario di Base della Lingua Italiana. Roma: Bulzoni.

van Donselaar, W., Koster, M., \& Cutler, A. (2005). Exploring the role of lexical stress in lexical recognition. Quarterly Journal of Experimental Psychology A, 58(2), 251-273.

van Son, R. J. J. H., \& Pols, C. H. (1999). Perisegmental speech improves consonant and vowel identification. Speech Communication, 29, 1-22.

Vayra, M. (1996). Regole formali vs. regolarità fonetiche: Un caso di accorciamento compensativo in italiano. Quaderni del Laboratorio di Linguistica della Scuola Normale Superiore, 10, 149-151.

Zwitserlood, P. (1989). The locus of effects of sentential-semantic context in spoken-word processing. Cognition, 32, 25-64.

Zwitserlood, P., \& Schriefers, H. (1995). Effects of sensory information and processing time in spoken word recognition. Language and Cognitive Processes, 10, 121-136. 